\title{
Menarikkah Jabatan Kepala Sekolah Dasar di Indonesia dalam Pandangan Guru?
}

\author{
Cepi Safruddin Abdul Jabar' ${ }^{1}$, Imi Khuzaimi ${ }^{2}$, Dwi Esti Andriani ${ }^{1}$ \\ ${ }^{1}$ Universitas Negeri Yogyakarta, Yogyakarta, DIY, Indonesia \\ ${ }^{2}$ Program Pasca Sarjana Universitas Negeri Yogyakarta, Yogyakarta, DIY, Indonesia \\ corresponding author: Dwi Esti Andriani (e-mail: dwi_esti@uny.ac.id)
}

\begin{abstract}
Abstrak: Kepala sekolah berperan penting untuk keberhasilan sekolah. Namun, penelitian tentang kekepalasekolahan masih sedikit. Penelitian ini bertujuan untuk menggali pandangan guru tentang jabatan kepala sekolah dasar dan bagaimana mereka menyikapi tawaran rekrutmen dan seleksi calon kepala sekolah. Penelitian ini menggunakan pendekatan kualitatif untuk mengeksplorasi fenomena tersebut. Penelitian ini dilaksanakan di sekolah dasar di Propinsi Daerah Istimewa Yogyakarta, Jawa, Indonesia. Pengumpulan data dilakukan dengan wawancara tidak terstruktur kepada 11 orang guru sekolah dasar yang telah memenuhi syarat untuk mengikuti rekrutmen dan seleksi calon kepala sekolah. Mereka dipilih dengan metode purposive. Data penelitian diolah dengan teknik analisis data kualitatif. Wawancara juga dilakukan dengan kepala sekolah, pengawas, dan personil Dinas Pendidikan untuk kredibilitas data. Hasil penelitian menunjukkan bahwa guru memandang jabatan kepala sekolah dasar sebagai jabatan yang beban pekerjaannya berat, insentifnya rendah, dan juga membutuhkan peran kepemimpinan yang besar. Hampir semua guru sekolah dasar bersikap menolak untuk mengikuti rekrutmen dan seleksi calon kepala sekolah. Sebagian kecil sisanya menerima dengan terpaksa.
\end{abstract}

Kata kunci: kekepalasekolahan, kepemimpinan kepala sekolah, pekerjaan kepala sekolah

\section{Is the Primary School Principal Job in Indonesia Attractive in Teachers' Views?}

\begin{abstract}
The principal plays an important role for school success. However, studies on principalship are still rare. This study aimed to explore the teachers' views on the primary school principal job and how they were responding to the opportunity to participate in the recruitment and selection of prospective principals. This study applied a qualitative research approach to explore the phenomenon. This study was located at public primary schools in Daerah Istimewa Yogyakarta Province, Java, Indonesia. Unstructured interviews were conducted to collect data from 11 primary school teachers who had met the requirements to participate in the recruitment and selection of prospective principals. They were selected using the purposive sampling technique. The collected data were analysed using qualitative data analysis methods. Interviews with principals, supervisors, and District Education Office officers were also carried out to achieve credibility. The results show that, according to the teachers, the primary school principal job is heavy with low incentives. It also demands strong leadership. The majority of primary school
\end{abstract}


teachers is refusing to participate in the recruitment and selection of prospective principals. The very few who agree to participate consider their participation is by force.

Keywords: principalship, principal leadership, principal job

\section{PENDAHULUAN}

Kekepalasekolahan di Indonesia mengalami banyak perubahan selama kurang lebih dua dekade ini. Perubahan tersebut berkaitan erat dengan implementasi kebijakan prinsipprinsip manajemen berbasis sekolah (MBS) dalam pengelolaan satuan pendidikan sejak tahun 2003 (Republik Indonesia, 2003). MBS memberikan sekolah hak otonomi untuk membuat keputusan tentang alokasi dana dan sumber daya pendidikan. MBS juga mendorong partisipasi masyarakat dan pemangku kepentingan dalam pengelolaan sekolah (Firman \& Tola, 2008; 2012; Kementerian Pendidikan dan Kebudayaan, 2013a, 2013b; Shoraku, 2008; World Bank). Konsekuensinya adalah peran, tugas, dan tanggung jawab kepala sekolah menjadi lebih besar.

Kepala sekolah diharapkan mampu menjadi pengelola dan pemimpin sekolah yang profesional. Mereka dituntut mampu membuat rencana pengembangan sekolah jangka pendek dan menengah, mengelola keuangan sekolah secara transparan, melakukan pemantauan serta memberikan dukungan dan bimbingan yang efektif kepada guru (Ministry of Education \& Culture, 2013). Misalnya dalam proses perencanaan pengembangan sekolah, kepala sekolah diharapkan mampu melakukan analisis kekuatan, kelemahan, peluang, dan ancaman sekolah sekaligus menetapkan tujuan pendidikan yang realistis berdasarkan hasil analisis tersebut (Kementerian Pendidikan dan Kebudayaan, 2013b; Kementerian Pendidikan Nasional, 2011a).

Berbagai kebijakan terkait kekepalasekolahan telah dirumuskan dan diimplementasikan untuk menghasilkan kepala sekolah yang diharapkan. Salah satu kebijakan mendasar yaitu rekonseptualisasi peran dan tugas kepala sekolah. Di era desentralisasi pendidikan atau MBS, mereka adalah guru yang diberi tugas tambahan sebagai kepala sekolah (Kementerian Pendidikan Nasional, 2010; Republik Indonesia, 2008). Artinya, mereka adalah pendidik sekaligus pemimpin lembaga. Pada tahun 2018 , peran mereka sebagai pemimpin pendidikan semakin diperkuat. Kepala sekolah bukan lagi menjadi tugas tambahan, melainkan sebagai tugas utama. Kepala sekolah adalah "guru yang diberi tugas memimpin dan mengelola satuan pendidikan" (Kementerian 
Pendidikan \& Kebudayaan, 2018). Mereka mengajar hanya jika kondisi sekolah membutuhkan. Misalnya, ketika suatu hari terdapat guru yang tidak bisa melaksanakan tugas dan tanggung jawabnya terkait pengajaran karena alasan tertentu, kepala sekolah dapat menggantikannya.

Tugas utama kepala sekolah sebagai pemimpin dan manajer meliputi mengelola, mengembangkan kewirausahaan, dan supervisi (Kementerian Pendidikan dan Kebudayaan, 2018). Mengelola merupakan tugas manajerial kepala sekolah yang ditujukan untuk peningkatan mutu sekolah yang berorientasi pada pencapaian atau pelampauan standar nasional pendidikan. Pengembangan kewirausahaan merupakan tugas pengelolaan program pengembangan kewirausahaan yang mencakup perencanaan, pelaksanaan, dan evaluasi program. Supervisi pendidikan mencakup kegiatan merencanakan, melaksanakan, menindaklanjuti, dan mengevaluasi program supervisi kepada guru dan tenaga kependidikan (Kementerian Pendidikan dan Kebudayaan, 2018).

Pemerintah telah mengembangkan model baru program penyiapan kepala sekolah agar mereka yang diangkat mampu melaksanakan tugasnya dengan baik. Model penyiapan kepala sekolah yang baru ini dirintis tahun 2010. Program ini terdiri dari tiga tahap kegiatan yang terstandar yaitu rekrutmen dan seleksi, pendidikan dan pelatihan calon kepala sekolah (CKS), dan sertifikasi (Kementerian Pendidikan Nasional, 2011b; Ministry of Education \& Culture, 2013). Setiap kepala sekolah baru yang diangkat mulai tahun 2018 wajib melalui ketiga tahapan tersebut untuk bisa dinyatakan lulus pendidikan dan pelatihan CKS. Ketika mereka lulus, mereka mendapatkan surat tanda tamat pendidikan dan pelatihan (STTPL). Mereka juga mendapatkan nomor unik kepala sekolah (NUKS) yang digunakan untuk memenuhi syarat sekaligus bukti kelayakan sebagai kepala sekolah (LPPKS, 2016).

Tujuan program penyiapan CKS adalah menghasilkan kepala sekolah yang kompeten. Hal tersebut diukur dari tingkat penguasaan mereka pada standar kompetensi kepala sekolah yang ditetapkan pemerintah. Standar ini terdiri dari lima dimensi kompetensi yaitu kepribadian, manajerial, kewirausahaan, supervisi, dan sosial (Kementerian Pendidikan Nasional, 2007). Asumsinya adalah kepala sekolah yang menguasai standar kompetensi tersebut tentu mampu melaksanakan peran, tugas, dan tanggung jawab 'barunya' dengan baik. 
Program penyiapan kepala sekolah model baru tersebut telah menarik perhatian akademisi untuk menelitinya (Isjuandi \& Anan Sutisna, 2017; Juliyanti, 2019; Priyadi, 2017; Sumintono, 2017; Sumintono, Sheyopuri, Jiang, Misbach, \& Jumintono, 2015; Suyud, Andriani, Purwanto, 2018). Hasil studi awal menunjukkan temuan yang positif, misalnya, pendekatan isi dan metode pendidikan dan pelatihan CKS dipandang peserta lebih baik daripada pelatihan program penyiapan CKS yang diselenggarakan oleh pemerintah Kabupaten atau Kota (Sumintono, 2017). Hasil penelitian senada ditemukan oleh Juliyanti (2019) dan Suyud, Andriani, Purwanto (2018) yang mewawancarai lulusan program ini. Mereka berpendapat bahwa kurikulumnya komprehensif dan fasilitas pelatihannya memadai. Namun demikian, hasil studi mereka juga menemukan persoalan terkait program ini. Salah satunya adalah rendahnya minat guru sekolah dasar mengikuti rekrutmen dan seleksi CKS. Hasil penelitian baru-baru ini juga menguatkan temuan tersebut. Dinas Pendidikan kesulitan mendapatkan calon kepala sekolah dasar karena guru-guru tidak berminat menjadi kepala sekolah (Novitasari, 2020).

Rendahnya minat guru mengikuti rekruitmen dan seleksi calon kepala sekolah perlu mendapatkan perhatian, sebagaimana disepakati oleh banyak ahli sejak lebih dari 10 tahun yang lalu (Barty, Thomson, Blamore, \& Sachs, 2005). Jika tidak, kondisi ini akan menyulitkan Dinas Pendidikan atau distrik dalam upaya mendapatkan CKS yang potensial sebagaimana terjadi di berbagai negara, misalnya Amerika dan Australia (Chapman, 2005; Gronn \& Rawlings-Sanaei, 2003; Normore, 2006). Dampaknya adalah program penyiapan CKS tidak dapat menghasilkan CKS yang berkualitas.

Penelitian ini bermaksud merespon kondisi tersebut. Terlebih, penelitian tentang kekepalasekolahan beberapa tahun terakhir ini relatif masih sedikit dibandingkan dengan penelitian tentang guru, terlepas adanya kesadaran dan pemahaman tentang pentingnya peran kepala sekolah untuk keberhasilan sekolah (Doyle \& Locke, 2014). Akibatnya, banyak aspek kekepalasekolahan yang belum dipahami. Secara spesifik, penelitian ini bertujuan untuk menggali pandangan tentang jabatan kepala sekolah dari sisi guru sekolah dasar yang diharapkan menjadi CKS. Rumusan pertanyaan penelitian ini yaitu:

1. Seperti apa pandangan guru tentang jabatan kepala sekolah dasar?

2. Bagaimana guru sekolah dasar menyikapi tawaran mengikuti rekrutmen dan seleksi calon kepala sekolah? 
Harapannya, artikel ini dapat meningkatkan literatur internasional terkait kekepalasekolahan, khususnya kekepalasekolahan di Indonesia dan membantu siapapun yang perlu meningkatkan pemahaman terkait hal tersebut.

\section{METODE PENELITIAN}

Penelitian ini merupakan penelitian kualitatif yang bertujuan untuk mengeksplor daripada memberikan ekspalanasi atas suatu fenomena (Creswell, 2009). Penelitian dilakukan di sekolah dasar di wilayah Propinsi Daerah Istimewa Yogyakarta, Jawa, Indonesia selama kurang lebih 4 bulan. Subjek penelitian yaitu 11 guru sekolah dasar yang yang memenuhi syarat untuk mengikuti rekrutmen dan seleksi CKS. Mereka dipilih dengan teknik purposive. Pengumpulan data dari mereka dilakukan dengan wawancara tidak terstruktur secara mendalam (in depht interview). Harapannya, wawancara dapat mengalir secara alami karena sifatnya sensitif dan perlu dijaga kerahasiaannya. Informasi-informasi unik juga dimungkinkan tergali (Stake, 2010). Data wawancara direkam saat proses wawacara menggunakan alat perekam yang kemudian ditranskrip menggunakan program F4 versi 4.2 .

Penelitian ini menggunakan analisis data kualitatif. Tahapan analisis data yang dilakukan mengikuti model Creswell (2009) yaitu: 1) mengolah dan mempersiapkan data; 2) membaca keseluruhan data; 3) menganalisis lebih detail dengan meng-coding data; 4) menerapkan coding untuk mendeskripsikan hasil temuan; 5) menyajikan dan mendeskripsikan tema-tema dengan pendekatan naratif; dan 6) melakukan interpretasi atau memaknai data.

Trianggulasi sumber dilakukan untuk kredibilitas data. Caranya yaitu dengan melakukan crosscek data kepada kepala sekolah dan juga pengawas di wilayah penelitian. Mereka dipilih karena mereka memahami dan bersinggungan langsung dengan fenomena yang menjadi fokus penelitian. Peneliti juga melakukan member check untuk menghindari kesalahan peneliti dalam melakukan interpretasi data. Caranya yaitu peneliti mendiskusikan temuan penelitian kepada pihak-pihak yang dipertimbangkan kompeten, yaitu teman sejawat, dosen pembimbing, dan pejabat Dinas Pendidikan terkait. 


\section{HASIL}

Hasil penelitian menunjukan bahwa 1) guru memandang jabatan kepala sekolah dasar memiliki beban pekerjaan yang berat, insentif yang rendah, dan membutuhkan keterampilan kepemimpinan; 2) sikap guru sekolah dasar terhadap tawaran mengikuti rekrutmen dan seleksi CKS yaitu hampir semuanya menolak. Ada sebagian kecil guru yang menerima tawaran tersebut. Namun, mereka menerimanya dengan terpaksa. Hasil penelitiannya yang lebih detail disajikan sebagai berikut.

\subsection{Pandangan guru tentang jabatan kepala sekolah dasar}

Hasil penelitian menunjukkan bahwa guru-guru memandang pekerjaan kepala sekolah dasar berat. Indikasinya, menurut mereka, yaitu beban pekerjaannya yang banyak dan tanggung jawabnya yang besar namun insentif jabatannya rendah. Selain itu, jabatan kepala sekolah dasar juga dipandang membutuhkan menuntut peran kepemimpinan yang tinggi dengan kemampuan yang bagus. Berikut deskripsi hasil penelitiannya.

\subsubsection{Tugas dan tanggung jawab jabatan kepala sekolah dasar berat}

Para guru yang terlibat dalam studi ini mengungkapkan bahwa tugas dan tanggung jawab kepala sekolah dasar berat. Hal ini diindikasikan dari beban pekerjaan kepala sekolah yang banyak dan bermacam-macam, tuntutan tugas luar yang tinggi, alokasi waktu yang banyak (time consuming), dan tanggung jawab penuh pada semua kegiatan sekolah.

Salah seorang guru mengungkapkan tugas kepala sekolah yang banyak sebagai berikut.

Di kabupaten sini itu susah memang, paling susah untuk mendapatkan guru yang mau menjadi kepala sekolah. Ini karena masya Allah yang namanya kepala sekolah, pekerjaannya .... dibebani ini, dibebani ini, dibebani ini, dibebani ini, waduuuh. (W-14/WR/KS/14-04-2017/30)

Pandangan senada dikemukakan oleh salah seorang guru yang pernah diberi tugas menjabat kepala sekolah sementara. Dia berkata:

Iya, tugas kepala sekolah banyak. Dulu selama kepala sekolah di tempat saya sudah purna, saya juga kan yang ngatur. Jadi saya itu sudah mengalami itu semua, merasakan pekerjaan kepala sekolah. Laporan lah, rapat lah, dan semua minta segera. Pokoknya harus segera dikerjakan. Memang seperti itu lah yang saya rasakan. (W-10/RAB/G/20-04-2017/26)

Seorang guru menguatkan pendapat tersebut. Dia berkata: 
Pekerjaan kepala sekolah itu waduuuuuhhh banyak sekali, menyita waktu. Kalo sudah jadi kepala sekolah... sudah kita gak bisa kerja lain-lain ... habis waktu. (W9/YI/G/19-04-2017/6)

Lebih lanjut dia mengatakan bahwa seorang kepala sekolah tanggung jawabnya besar. Ia bertanggung jawab pada semua aktivitas yang berjalan di sekolah. Dia berkata,

"kepala sekolah tanggung jawabnya pada sekolah penuh, urus ini, urus itu..." (W3/SU/G/29-03-2017/6).

Salah seorang guru menambahkan. Ia mengatakan bahwa kepala sekolah juga harus sering keluar sekolah untuk melaksanakan tugas dinasnya.

Guru lain yang diwawancara mengungkapkan tugas dan tanggung jawab berat kepala sekolah dengan memberikan deskripsi pekerjaannya yang kompleks karena seringkali melibatkan banyak pihak. Dia mengatakan:

Di sekolah itu kan sedikit-sedikit jadi masalah, kompleks sekali, dengan siswa, dengan masyarakat, dengan wali murid dengan sesama guru. Seperti ini bisa jadi ribut di belakang kita (W-1/ST/G/29-03-2017/17).

Kepala sekolah sependapat dengan pandangan tersebut. Salah seorang kepala sekolah kemudian menambahkan bahwa pandangan tersebut seringkali menjadi alasan guru sekolah dasar tidak beminat menjadi kepala sekolah. Ia mengatakan:

"respon guru untuk menjadi kepala sekolah itu rendah. Ini karena pekerjaan sebagai kepala sekolah berat" (W-16/AH/KS/18-04-2017/8).

NU salah seorang kepala sekolah dasar yang juga diwawancara menceritakan tugas pekerjaan kepala sekolah dasar yang bermacam-macam dan sulit. Melihat pekerjaan ini, banyak guru yang merasa tidak siap menjadi kepala sekolah. NU berkata,

Tugas kepala sekolah itu sangat berat. Di sini itu berat sekali. Selain tugas manajerial termasuk nanti sebagai supervisor ada tambahan-tambahan sebagai administratornya. Nuwun sewu ya maaf ya, kadang-kadang ada guru yang menggunakan IT kurang mampu, nanti susah kan. Nanti atasan ada yang bilang itu alasan klasik. Oleh karena itu, memang banyak guru merasa tidak siap menjalankan tugas ini. Kalau ada sesuatu terkait laporan yang dikejar bukan guru, tapi kepala sekolah. Itu apapun nanti yang dipanggil kan kepala sekolah. Guru bermasalah, kepala sekolahnya dulu. Itu kalau yang saya tahu. Kalo jadi guru kan ya tugasnya tinggal dilaksanakan, selesai, enjoy.(W-13/NU/KS/08-04-2017/11)

Situasi di atas menunjukkan bahwa guru memandang jabatan kepala sekolah dasar berat, dilihat dari tugas pekerjaan, dan tanggung jawabnya. Tugas pekerjaannya banyak meliputi tugas manajerial, "mengurus orang”, supervisi, dan juga administrasi yang seringkali dilaksanakan dalam kondisi sulit misalnya guru-guru tidak menguasai 
teknologi informasi. Tanggung jawabnya besar, meliputi semua aktivitas di sekolah. Tugas dan tanggung jawab ini dipandang menyita waktu dan seringkali mengharuskan kepala sekolah untuk dinas luar.

\subsubsection{Insentif jabatan yang rendah}

Hasil penelitian menunjukkan bahwa guru-guru memandang insentif jabatan kepala sekolah dasar rendah. Pandangan mereka ini didasarkan pada perbandingan antara beban pekerjaan kepala sekolah yang tinggi dan besaran insentifnya atau besaran penghasilan dari pekerjaan sampingan yang bisa dilakukan jika mereka tidak menjabat kepala sekolah dasar.

Insentif kepala sekolah saat ini menurut guru rendah, tidak sebanding dengan beban tugas dan tanggung jawabnya. Salah seorang guru mengungkapkan hal ini sebagai berikut.

Guru sama kepala sekolah perbedaan penghasilannya sedikit, tapi pekerjaan kepala sekolah jauh lebih banyak. (W-18/SS/PS/02-05-2017/20)

Hal senada dikemukakan oleh guru yang lain. Dia berkata:

Tanggung jawabnya berat namun tunjangannya nggak ada bedanya dengan guru cuma tambah beban. (W-16/AH/KS/18-04-2017/9)

Guru tersebut juga mengatakan bahwa insentif yang rendah tersebut merupakan salah satu kondisi yang menyebabkan jabatan kepala sekolah dasar tidak menarik bagi sebagian guru.

Insentif jabatan yang rendah juga dilihat dari perbandingannya dengan penghasilan guru ketika mereka melakukan pekerjaan lain. Salah seorang guru mengungkapkan hal tersebut sebagai berikut.

Tugas berat, tunjangan gak sebanding. Jadi dihitung-hitung ya pilih mengerjakan pekerjaan yang lain. Teman-teman saya guru olah raga "mending jual bola". Teman saya yang punya peternakan pilih ternak, penghasilan OK. Gak usah tanggung jawab macam-macam gitu saja. Saya saja di rumah ngeles di rumah sebulan dapat delapan ratus, sembilan ratus kan beres. Jadi kepala sekolah gak sampai segitu sibuk habis waktu. (W-2/PA/G/29-03-2017/19)

Berdasarakan uraian di atas dapat disimpulkan bahwa guru memandang insentif jabatan kepala sekolah dasar rendah sehingga jabatan ini kurang menarik dibandingkan dengan pekerjaan yang lain. 
3.1.3. Jabatan kepala sekolah dasar membutuhkan keterampilan kepemimpinan

Hasil penelitian menunjukkan bahwa guru memandang jabatan kepala sekolah dasar sebagai jabatan yang membutuhkan keterampilan kepemimpinan seperti mengatur orang lain, membimbing, bekerja sama, berkomunikasi, dan menjaga keharmonisan hubungan. Sebagian besar dari mereka memandang keterampilan-keterampilan tersebut sulit dan tidak semua hal tersebut dikuasai guru, termasuk oleh diri mereka sendiri.

Seorang kepala sekolah harus mampu mengatur orang lain. Salah seorang guru berkata:

Seorang kepala sekolah harus bisa mengatur teman-teman.... (W-3/SU/G/29-032017/6).

Guru lain menambahkan. Menurutnya, seorang kepala sekolah tidak hanya harus mampu mengatur, namun juga membimbing teman-temannya. Seorang guru berkata:

Kalau jadi kepala sekolah kan harus bisa membimbing apalagi kalau ada macammacam persoalan misalnya dalam menghadapi guru-guru. Dia harus bisa menjaga keharmonisan (W-10/RAB/G/20-04-2017/22).

Pandangan senada dikemukakan oleh guru TR. Ia berkata:

Kepala sekolah harus mampu membimbing orang-orang tua, kan nggak enak membimbing yang lebih senior (W-4/TR/G/04-04-2017/14).

Guru-guru juga mengungkapkan bahwa keterampilan mengatur orang lain, membimbing, dan lain-lain yang berhubungan dengan orang tidak lah mudah. Menurut mereka, tidak semua guru menguasai keterampilan tersebut. Hal ini diungkapkan oleh YI sebagai berikut.

Kalau jadi kepala sekolah itu sulit, membangun kerjasama yang bagus dengan rekan kerja itu sulit, gimana berkomunikasi yang pas sulit ... pokoknya sulit, memimpin itu sulit (W-9/YI/G/19-04-2017/3).

Seorang guru menyampaikan hal serupa. Ia mengatakan:

kalau jadi kepala sekolah, komunikasinya ke rekan kerja itu berbeda, harus gimana gitu, sulit, cara berbicara harus diperhatikan, pokoknya sulit. Saya merasa belum mampu (W-9/YI/G/19-04-2017/3).

Situasi tersebut menggambarkan bahwa jabatan kepala sekolah dasar membutuhkan penguasaan berbagai keterampilan kepemimpinan. Banyak guru sekolah dasar yang merasa diri mereka tidak menguasai keterampilan tersebut. 


\subsection{Sikap guru sekolah dasar terhadap tawaran mengikuti rekrutmen dan seleksi calon kepala sekolah}

Hasil penelitian menunjukkan bahwa semua guru sekolah dasar pada dasarnya menolak tawaran mengikuti rekrutmen dan seleksi CKS. Guru sekolah dasar yang menerima sangat sedikit. Mereka menerima tawaran tersebut dengan terpaksa sebagai bentuk kepatuhan dan loyalitas kepada atasan.

\subsubsection{Menolak}

Semua guru sekolah dasar yang terlibat dalam studi ini mengungkapkan bahwa pada dasarnya mereka menolak tawaran rekrutmen dan seleksi CKS. Mayoritas guru menolaknya sejak awal saat mereka ditawari. Berikut hasil penelitiannya.

Guru sekolah dasar menolak tawaran pencalonan kepala sekolah sejak pertama kali ditawari. Salah seorang guru menyampaikannya sebagai berikut.

Pekerjaan kepala sekolah menyita waktu saya. Saya tidak mau. Jadi saya itu pernah diajukan tapi belum pernah maju karena memang tidak bersedia. (W-9/SU/G/1904-2017/6)

Guru lain mengungkapkan sikap senada sebagai berikut.

Saat itu, teman saya di madrasah ibtidaiyah bilang nama saya sudah tercatat sebagai guru yang dicalonkan. Lalu teman saya bilang ayo maju, saya jawab saya nggak mau. Saya memang tidak minat. (W-9/TR/G/19-04-2017/3)

YI, seorang guru, mengungkapkan bahwa dia berupaya untuk tidak diusulkan dalam proses rekrutmen dan seleksi CKS. Dia ingin tetap menjadi guru. Dia berkata:

Saya kan sudah 2 kali ditawari menjadi bakal calon kepala sekolah. Yang pertama saya menolak, yang kedua juga saya tetap tidak mau. Saya sudah menolak sebelum diajukan. Jadi saya bukan guru yang ikut tes dan tidak lulus. Saya memang belum pernah diajukan karena ya tadi saya sudah menolak duluan saat ditawari oleh kepala sekolah dan pengawas. Intinya saya itu tetap jadi guru saja. (W-9/YI/G/19-042017/6)

Sikap penolakan guru sekolah dasar pada tawaran pencalonan kepala sekolah menunjukkan bahwa jabatan kepala sekolah dasar tidak menarik bagi mereka.

Kepala sekolah yang diwawancara membenarkan adanya penolakan pencalonan kepala sekolah dari sebagian besar guru sekolah dasar. Salah satu alasan penolakannya, menurut dia, terkait dengan resiko pekerjaan mengelola keuangan.

Iya, banyak guru yang menolak. Mereka banyak yang ketakutan. Pekerjaan kepala sekolah memang berat dan sulit juga. Pengelolaan itu kan banyak ancamannya gitu terutama yang berkaitan dengan keuangan. Itu yang membuat mereka merasa berat (W-18/SS/PS/02-05-2017/20). 
Hal senada disampaikan salah seorang kepala sekolah. Ia mengatakan bahwa minat guru untuk menjadi kepala sekolah rendah. Namun, alasannya lebih pada tanggung jawab jabatan yang dipandang guru sangat berat (W-16/AH/KS/18-04-2017/8).

\subsubsection{Menerima dengan "terpaksa"}

Hasil penelitian menunjukkan bahwa ada sebagian kecil guru sekolah dasar yang bersedia mengikuti rekrutmen dan seleksi CKS. Dasar pertimbangannya yaitu, sebagaimana mereka ungkapkan, kepatuhan dan loyalitas kepada atasan. Loyalitas ini mereka rasakan seperti keharusan ketika keikutsertaan mereka dalam pencalonan CKS diwajibkan.

Guru sekolah dasar yang menerima tawaran mengikuti rekrutmen dan seleksi CKS mengatakan bahwa mereka dipaksa. Salah seorang guru menceritakan hal ini sebagai berikut.

Ya, memang di kabupaten in pernah terjadi, tahun berapa itu, Kepala Dinasnya memberikan instruksi kepada Kepala UPT agar guru yang telah memenuhi syarat bersedia mengikuti pencalonan kepala sekolah, kemudian Kepala UPT seperti menekan para guru SD. Mereka bilang: "yang sudah memenuhi syarat semua harus ikut seleksi. (W-14/WR/KS/14-04-2017/10)

Salah seorang guru olah raga menguatkan pernyataan di atas. Dia mengatakan:

Guru olah raga yang gak berminat di kecamatan sini hampir semua, 99\% dari 40 yang sudah memenuhi persyaratan. Hanya dua orang kemarin yang mau karena terpaksa. Itu pak A bilang "aku dipaksa, saya nggak senang sebenarnya", yang satu lagi tinggal menunggu penempatan juga sama. Jadi 2 orang saja yang mau. Hanya itu. (W-6/KUS/G/17-04-2017/7)

Pandangan KUS, yang juga guru olah raga menguatkan pernyataan tersebut. Dia mengatakan:

Teman saya yang akrab dengan saya, pak Y itu. Dia kan sering main bulu tangkis dengan saya. Dia bilang "saya itu nggak minat, tapi saya dipaksa. Kata saya kalau nggak mau kan nggak usah jadi kepala sekolah, "tapi saya dipaksa terus", katanya. (W-6/KUS/G/17-04-2017/11).

Pernyataan guru RAB semakin menegaskan pandangan bahwa umumnya guru menolak mengikuti pencalonan kepala sekolah. Jika ada yang menerima, mereka memang benarbenar terpaksa. Dia berkata:

Kalau secara umum, jumlah peminat jabatan kepala sekolah memang di bawah standar yang diharapkan Dinas, banyak yang nggak mau. Kata yang sudah mengikuti diklat kepala sekolah, saya tanya "Sudah mantap toh 'tuk jadi kepala sekolah", "Apa, dipaksa kok, ' $g a h "$. (W-10/RAB/G/20-04-2017/23)

Dia menambahkan bahwa ada guru yang dicalonkan yang sengaja tidak serius mengikuti pendidikan dan pelatihan CKS. Tujuannya adalah agar dirinya tidak lulus sehingga dia tidak memenuhi syarat untuk diangkat menjadi kepala sekolah. 
TR, salah seorang guru yang mengajar mata pelajaran olah raga mengatakan bahwa dirinya tidak serius mengikuti proses seleksi CKS. Dia berkata:

Saya sekarang sudah umur 55 mas. Ya memang 3 atau 4 tahun yang lalu saya diusulkan, tapi untuk seleksi saya tidak lulus karena saya tidak serius mengikutinya, saya memang tidak ada minat. (W-4/TR/G/04-04-2017/11)

Salah seorang guru menguatkan hal tersebut. Dia berkata,

Saya tahu, guru-guru yang mau dicalonkan itu sekadar ikut aja karena anjuran atau paksaan dari atas. Ini ngawekani mempersiapkan kepala sekolah yang dibutuhkan, kok semua tidak berminat bagaimana. (W-3/SU/G/29-03-2017/11)

Situasi di atas menunjukkan jabatan calon kepala sekolah tidak diminati oleh guru sekolah dasar. Mereka menolak untuk mengikuti rekrutmen dan seleksi CKS bilamana memungkinkan.

\section{PEMBAHASAN}

Pembahasan ini disajikan dalam dua bagian sesuai pertanyaan penelitian yang telah dirumuskan. Pokok-pokok hasil penelitian akan dideskripsikan terlebih dahulu secara singkat sebelum pembahasan untuk memudahkan pemahaman atas fenomena yang dikaji.

\subsection{Pandangan guru tentang jabatan kepala sekolah dasar}

\subsubsection{Tugas dan tanggung jawab jabatan kepala sekolah dasar berat}

Hasil penelitian menunjukkan bahwa guru memandang pekerjaan kepala sekolah dasar berat. Pekerjaannya mencakup berbagai macam pekerjaan manajerial, supervisi, dan juga administrasi yang seringkali dilaksanakan dalam kondisi sulit, misalnya, guru-guru tidak mampu memanfaatkan teknologi informasi. Tanggung jawabnya juga besar yaitu meliputi semua aktivitas di sekolah. Tugas dan tanggung jawab ini dipandang menyita waktu. Oleh karenanya, mereka tidak tertarik atau berminat menjadi kepala sekolah.

Hasil penelitian ini mendukung hasil penelitian sebelumnya. Implementasi desentralisasi pendidikan atau MBS telah meningkatkan peran, tugas dan tanggung jawab kepala sekolah. Pekerjaan mereka menjadi lebih banyak (Chapman, 2005). Hasil studi di Amerika menunjukkan bahwa kepala sekolah sekarang menghadapi harapan pemerintah dan tuntutan orang tua murid yang semakin tinggi, dan juga beragam pekerjaan terkait peningkatan mutu sekolah, pembuatan laporan tahunan, akuntabilitas, kurikulum, keamanan siswa, isu gender dan keadilan, misi tujuan, hasil pendidikan, pengembangan 
siswa, dan juga akreditasi (Cusick, 2003). Di saat yang bersamaan, mereka seringkali kekurangan sumber dana dan dukungan pendidikan dari orang tua dan masyarakat (Styron \& Styron, 2011; Whitaker, 2003; Wise, 2015). Dari banyaknya tantangan tersebut, tuntutan akuntabilitas berupa nilai ujian siswa yang tinggi serta penerapan ujian terstandar sebagai kriteria penentu skor kinerja sekolah dan prestasi siswa merupakan isu yang dirasakan paling krusial dan membuat para kepala sekolah mengalami stres (Styron \& Styron, 2011). Terlebih, otoritas yang diberikan kepada mereka dalam pengelolaan sumber daya sekolah seringkali tidak sebanding dengan tanggung jawab yang dibebankan (Doyle \& Locke, 2014). Oleh karenanya, tidak mengherankan jika pekerjaan kepala sekolah dirasakan sangat melelahkan.

Pekerjaan kepala sekolah yang berat semakin nampak di sekolah-sekolah dalam lingkungan yang sulit, misalnya sekolah di daerah terpencil. Mereka tidak hanya dihadapkan pada tugas manajemen namun juga pengajaran sebagaimana dialami oleh kepala sekolah di Australia dan Inggris (Clarke \& Wildy, 2004; Halsey, Drummond, \& Breda, 2010; Tuck, 2009; Wilson \& Brundrett, 2005). Tanggung jawab manajemen mengharuskan mereka, misalnya, merevisi dan memperbarui dokumen sekolah termasuk rencana strategis sekolah dan kebijakan sekolah (Clarke \& Wildy, 2004). Di saat yang bersamaan mereka juga harus mengajar siswa dari beragam kelas/tingkat dalam satu rombongan belajar serta mempersiapkan dan menulis berbagai dokumen pengajaran (Clarke \& Wildy, 2004; Wilson \& Brundrett, 2005). Mayoritas kepala sekolah dasar harus mengerjakan tugas-tugas mereka secara mandiri. Mereka tidak memiliki wakil kepala sekolah, asisten atau guru untuk membantu dan berbagi tanggung jawab (Clarke \& Stevents, 2009; Clarke \& Wildy, 2004; Sayce \& Lavery, 2013).

Situasi serupa terjadi di sekolah-sekolah terpencil di negara berkembang, Hasil studi menunjukkan bahwa di negara ini, kepala sekolah berkewajiban mengajar dan mengelola (Lingam, Lingam, \& Raghuwaiya, 2014; Plessis, 2014). Tugas pekerjaan tersebut berat. Penyebabnya yaitu selain tidak memiliki staf untuk membantu, mereka seringkali tidak memiliki kemampuan kerja yang memadai. Teknologi yang dibutuhkan seperti koneksi internet juga kurang mendukung. Namun, sekolah tidak memiliki dana yang memadai untuk menyediakannya. Akibatnya, mereka sering kekurangan waktu untuk menyelesaikan pekerjaan mereka. Juga, beban pekerjaan yang tinggi pada manajemen dan pengajaran sering menimbulkan 'tension' di antara keduanya (Plessis, 
2014). Di saat bersamaan, tuntutan peran supervisi tinggi karena banyak guru yang kurang kompeten (Lingam, dkk., 2014) sebagaimana juga dialami oleh kepala sekolah di daerah terpencil di Indonesia (Andriani, Clarke \& O’ Donoghue, 2019).

Pekerjaan kepala sekolah yang banyak dan kompleks dapat menurunkan daya tarik jabatan kepala sekolah. Hasil penelitian menunjukkan bahwa penyebab utama jabatan kepala sekolah di Amerika tidak menarik adalah pekerjaannya yang banyak dan berat (Cusick, 2003; Doyle \& Locke, 2014; Renihan, 1999). Memperhatikan hal tersebut, program penyiapan kepala sekolah hendaknya dapat benar-benar membekali kepala sekolah kemampuan yang dibutuhkan untuk menghadapi berbagai tantangan pekerjaannya (Wise, 2015). Kepala sekolah juga perlu mendapatkan dukungan yang memadai seperti pelatihan dalam jabatan untuk mendukung kemampuan kerja yang membutuhkan pengetahuan, keterampilan, dan sikap baru. Jika tidak, jabatan ini menjadi kurang menarik dan jumlah peminatnya akan menurun (Chapman, 2005).

\subsubsection{Insentif jabatan yang rendah}

Hasil penelitian juga menunjukkan bahwa insentif jabatan kepala sekolah dasar rendah. Pandangan ini didasarkan pada perbandingan antara beban dan tanggung jawab kepala sekolah yang besar dengan insentif jabatan kepala sekolah atau penghasilan dari pekerjaan sampingan yang bisa dilakukan guru jika mereka tidak menjabat sebagai kepala sekolah.

Hasil penelitian ini selaras dengan temuan studi sebelumnya. Hasil studi di Amerika menunjukkan bahwa insentif jabatan kepala sekolah dipandang relatif rendah atau tidak sebanding dengan beban pekerjaannya (Boyle \& Locke, 2014; Cusick, 2003; Renihan, 1999). Kondisi ini menjadi salah satu penyebab utama kedua setelah karateristik pekerjaan kepala sekolah yang berat, yang menyebabkan jabatan kepala sekolah tidak menarik (Boyle \& Locke, 2014; Renihan, 1999) khususnya bagi guru-guru yang telah menikah dan berpenghasilan cukup (Cusick, 2003). Untuk mengatasi permasalahan ini, hasil studi menyarankan peningkatan insentif jabatan kepala sekolah jika memungkinkan (Nomore, 2006) atau mengangkat kepala sekolah yang masih muda (Cusick, 2003). Asumsinya, penghasilan mereka relatif masih rendah sehingga insentif jabatan kepala sekolah yang dipandang rendah bisa berarti besar bagi mereka.

Terkait dengan isu insentif tersebut, Normore (2006) mengungkapkan kondisi yang berbeda di masa lalu. Dahulu, memposisikan kembali guru ke jajaran administrator 
sekolah relatif mudah karena pendidik melihat administrasi sebagai bagian dari peningkatan karir. Secara tradisional, jika guru ingin mendapatkan lebih banyak uang, mencapai status yang lebih tinggi, atau mendapatkan rasa hormat yang lebih besar, mereka akan meninggalkan ruang kelas dan bergerak menuju jabatan kepala sekolah atau peran administrasi lainnya. Sekarang, guru tidak lagi melihat administrasi sebagai cara untuk meningkatkan gaji, prestise, atau rasa hormat mereka diantara rekan kerja lainnya (Normore, 2006) sehingga ketika mereka ditawari mengikuti rekrutmen dan seleksi calon kepala sekolah, reaksinya negatif.

4.1.3. Jabatan kepala sekolah dasar membutuhkan keterampilan kepemimpinan yang bagus

Hasil penelitian juga menunjukkan bahwa guru memandang kepala sekolah dasar sebagai jabatan yang membutuhkan berbagai keterampilan kepemimpinan. Keterampilan ini meliputi keterampilan 'mengurus orang', membimbing guru, berkomunikasi dengan baik, membangun kerjasama, dan menjaga keharmonisan hubungan dengan orang lain. Berdasarkan pandangan mereka, berbagai keterampilan ini relatif sulit dan tidak semua guru menguasainya.

Hasil penelitian ini selaras dengan hasil-hasil riset saat ini yang menunjukkan bahwa jabatan kepala sekolah membutuhkan peran kepemimpinan yang melampaui peran manajerialnya. Di abad 21 ini, dimana desentralisasi pendidikan atau MBS telah menjadi kebijakan untuk diimplementasikan, kepala sekolah perlu penekanan yang lebih pada peran kepemimpinan daripada manajemen (Caldwel, 2010; Mulford, 2010). Selain itu, sekolah dihadapkan pada perubahan yang cepat dan juga tidak pasti. Di Indonesia, kepala sekolah menghadapi beberapa kali pergantian kurikulum dalam kurun waktu yang singkat sejak awal tahun 2000. Pemerintah memperkenalkan kurikulum baru tahun 2004 yang dikenal dengan kurikulum berbasis kompetensi (KBK). Hanya selang 2 tahun kemudian, tahun 2006, kurikulum ini diperbaharui dan tepat 7 tahun setelahnya, kurikulum 2006 yang dikenal dengan sebutan kurikulum tingkat satuan pendidikan (KTSP) diganti dengan kurikulum 2013 (Ministry of Education \& Culture, 2013). Kurikulum 2013 dan perangkatnya tersebut hingga kini terus mengalami pengembangan. Situasi tersebut menuntut kepala sekolah untuk bisa menjadi pemimpin transformasional yang mampu memimpin guru-guru di sekolah mereka untuk mensukseskan tuntutan perubahan pendidikan tersebut (Ministry of National Education, 2006). Hal ini seringkali tidak 
mudah ketika kondisi sumber daya kurang mendukung karena sekolah berada dalam kondisi sulit, misalnya di daerah terpencil dimana guru-gurunya memandang bahwa keefektifan implementasi kurikulum 2013 belum pasti (Andriani, 2017). Tuntutan perubahan yang cepat dan penuh ketidakpastian ini dipicu oleh kemajuan ilmu pengetahuan dan teknologi yang begitu cepat, globalisasi yang meningkat, perubahan demografi, dan juga tekanan dari lingkungan (Bottery, 2010; Mulford, 2010)

Kebutuhan keterampilan kepemimpinan dari kepala sekolah selaras dengan hasil penelitian terkini. Kepala sekolah yang berhasil adalah kepala sekolah yang memiliki kepemimpinan yang bagus (Marzano, Waters, \& McNulty, 2005; NASSP \& NAESP, 2013). Pengaruhnya sangat kuat terhadap proses dan hasil pembelajaran siswa walaupun tidak secara langsung. Pengaruhnya dimediasi oleh berbagai faktor (Hallinger \& Heck, 1998; Leithwood, Louis, Anderson, and Wahlstrom, 2004; Leithwood, Harris, Hopkins, 2008; Sun \& Leithwood, 2015) seperti kapasitas, motivasi, komitmen dan kondisi kerja guru (Leithwood, dkk., 2008; Leithwood, 2007; Leithwood \& Levin, 2010).

Hasil penelitian ini juga menunjukkan bahwa kemampuan kepemimpinan yang dituntutkan tidak lah mudah. Oleh karena itu, sebagian besar guru sekolah dasar merasa belum mampu menjadi kepala sekolah. Terkait hal ini, Chapman (2005) menegaskan perlunya pelatihan dan dukungan pekerjaan yang memadai bagi kepala sekolah. Jika tidak, hal ini akan menimbulkan isu pada kepuasan kerja, rekrutmen, retensi kepala sekolah dan juga pengembangan kepemimpinan sekolah. Mendukung pendapat tersebut, Cusick (2003) menegaskan bahwa pelatihan yang diberikan perlu berorientasi pada reformasi sekolah yang diharapkan. Pemerintah juga perlu memberikan waktu kepada kepala sekolah untuk pengembangan profesional berkelanjutan, dan meninjau kembali harapan peran kepala sekolah, realistis atau tidak (Cusick, 2003). Selain itu, alternatif model kekepalasekolahan misalnya kepala sekolah lebih dari satu pada suatu sekolah dengan bidang tugas masing-masing yang berbeda atau kepala sekolah-wakil kepala sekolah bisa dicoba untuk mengurangi beban pekerjaan kepala sekolah (Chapman, 2005; Zeitoun \& Newton, 2002). Harapannya, jabatan kepala sekolah dapat lebih menarik dan tidak lagi dipandang sulit dan berat. 


\subsection{Sikap guru sekolah dasar terhadap tawaran mengikuti rekrutmen dan seleksi calon kepala sekolah}

\subsubsection{Menolak}

Hasil penelitian menunjukkan guru sekolah dasar menolak untuk mengikuti rekrutmen dan seleksi CKS. Mereka tidak berminat mengikuti proses tersebut dengan beberapa pertimbangan diantaranya, sebagaimana telah disampaikan sebelumnya, pekerjaan kepala sekolah yang berat dan insentif jabatan yang rendah.

Hasil penelitian ini selaras dengan kondisi di negara-negara lain seperti di Amerika dan Australia (Chapman, 2005; Cusick, 2003; Hine, 2003; Gronn \& RawlingsSanaei, 2003; Whitaker, 2003; Zeitoun \& Newton, 2002). Di Michigan misalnya, jumlah guru yang siap, qualified, dan mau menjadi kepala sekolah menurun, 1/2 atau 2/3 dibandingkan 15 tahun yang lalu. Fenomena ini juga terjadi di banyak distrik lainnya. Selain itu, hasil penelitian juga menunjukkan bahwa sedikit sekali guru yang telah memegang sertifikat kepala sekolah berminat menjadi kepala sekolah (Cusick, 2003; Hine, 2003). Bahkan, banyak kepala sekolah di Amerika yang meninggalkan pekerjaan ini dan distrik kesulitan mencari penggantinya. Jika mendapatkan pengganti, seringkali penggantinya tidak memiliki keterampilan sebagai administrator sekolah (Hine, 2003). Selain itu, angka keluar masuk kepala sekolah juga tinggi. Kondisi ini dapat mengganggu upaya penyelenggaraan persekolahan yang efektif (Chapman, 2005).

\subsubsection{Menerima dengan "terpaksa"}

Hasil penelitian juga menunjukkan ada sebagian kecil guru yang bersedia mengikuti rekrutmen dan seleksi CKS. Namun, mereka menerima tawaran tersebut dengan terpaksa sebagai bentuk kepatuhan atau loyalitas pada atasan mereka (Dinas Pendidikan, kepala sekolah, dan pengawas).

Normore (2006) mengatakan bahwa metode penunjukkan atau pemilihan oleh kepala sekolah atau pengawas "tapping the candidates" bisa digunakan dalam perekrutan CKS (Normore, 2006). Namun, metode tersebut, walaupun tidak salah, tidak bisa mengidentifikasi dengan baik bakat kepemimpinan guru (Doyle \& Locke, 2014) yang penting untuk dipertimbangkan. Davis \& Hammond (2012) dan Gene, Neill, Betty, David (2003) mengatakan bahwa rekrutmen CKS perlu mempertimbangkan pemahaman individu tentang kurikulum dan pembelajaran, motivasi menjadi kepala sekolah, dan 
keinginan untuk membantu siswa mencapai standar prestasi yang tinggi. Jika aspek-aspek tersebut, maka rekrutmen akan sulit mendapatkan CKS yang potensial.

Sistem rekrutmen perlu dikembangkan untuk menghasilkan CKS yang potensial. Terkait hal ini, Normore (2006) dan Doyle \& Lock (2014) menyarankan perlunya penerapan sistem rekrutmen ekternal untuk meningkatkan jumlah calon disamping rekrutmen internal bilamana memungkinkan. Namun demikian, Normore (2006) mengatakan bahwa rekrutmen internal memiliki keunggulan dibandingkan rekrutmen eksternal yaitu memperoleh calon yang sudah memahami budaya yang disepakati. Rekrutmen juga perlu mempertimbangkan calon kepala sekolah perempuan yang gaya kepemimpinannya cenderung demokratis. Hal lain yang perlu dilakukan adalah kepala sekolah atau pengawas perlu membujuk calon potensial untuk mencalonkan diri mereka sebagai kepala sekolah (Doyle \& Locke, 2006; Normore, 2006). Selain itu, rekrutmen perlu melibatkan pemerintah daerah terkait misalnya Dinas Pendidikan yang menaungi atau membina sekolah. Mereka bisa dilibatkan dalam penetapan prosedur rekrutmen dan kriteria calon karena mereka lah yang mengetahui kualitas kepala sekolah yang dibutuhkan (Davis \& Hammond, 2012; Normore, 2006).

\section{SIMPULAN}

Jabatan kepala sekolah dasar di Indonesia secara umum dipandang tidak menarik oleh guru. Jabatan ini dinilai memiliki beban kerja dan tanggung jawab yang berat namun insentifnya rendah. Selain itu, pekerjaan ini membutuhkan keterampilan kepemimpinan yang dipandang sulit dan tidak semua guru menguasainya. Pandangan tersebut telah menjadi alasan sikap guru-guru sekolah dasar menolak untuk mengikuti rekrutmen dan seleksi CKS. Hanya sedikit sekali guru yang menerima tawaran tersebut karena terpaksa sebagai bentuk kepatuhan atau loyalitas kepada atasan.

Penelitian ini menyarankan perlunya pengembangan kebijakan yang diarahkan untuk meningkatkan daya tarik jabatan kepala sekolah dasar. Kebijakan yang dimaksud antara lain rekonseptualisasi peran kepala sekolah dasar, peningkatan insentif jabatan, pengembangan kepemimpinan sekolah, support pekerjaan yang memadai, penerapan berbagai alternatif model kekepalasekolahan, dan pengembangan sistem rekrutmen yang lebih responsif terhadap kebutuhan maupun kondisi lapangan. Penelitian ini juga merekomendasikan perlunya penelitian dalam skala yang besar terkait kondisi pekerjaan 
kepala sekolah di berbagai tingkatan sekolah dan di beragam konteks serta bagaimana minat atau motivasi pada diri para guru di sekolah tersebut untuk menjadi kepala sekolah. Penelitian tersebut akan bermanfaat bagi siapapun yang ingin meningkatkan pemahaman atau mengembangkan kepemimpinan sekolah di Indonesia.

\section{Acknowledgment}

Penelitian ini tidak menerima dana dari institusi pemerintah maupun swasta.

\section{DAFTAR PUSTAKA}

Andriani, D. E. (2017). Leadership at the primary school level in Indonesia: A study of the historical background, recent developments, and current concerns of school leaders in a postcolonial and developing country (Doctoral thesis). University of Western Australia.

Andriani, D. E., Clarke, S., O’ Donoghue (2019). Charting primary school leadership in Indonesia from centralisation to decentralisation era. In Tom O' Donoghue \& Simon Clarke (Eds.). The theory and history of education. Monograph Series Vol. 1: New directions in research on education reconstruction in challenging circumstances. (pp. 93-112). Kingston: The Queens' University.

Barty, K., Thomson, P., Blamore, J., \& Sachs, J. (2005). Unpacking the issues: researching the shortage of school principals in two states in Australia. The Australian Educational Researcher, 32(3), 1-18.

Bottery, M. (2010). Contexts for leadership at the beginning of th 21 st century. International Encyclopedia of Education ( $\left.3^{\text {rd }} \mathrm{ed}\right)$. Melbourne: Elsevier Science \& Technology.

Caldwell, B. J. (2010). School reform and restructuring: self-managing school International Encyclopedia of Education ( $3^{\text {rd }} \mathrm{ed}$ ). Melbourne: Elsevier Science \& Technology.

Chapman, J. D., (2005). Recruitment, retention, and development of school principals. Paris \& Brussels: IIEP \& IAE. Retrieved from https://unesdoc.unesco.org/ark:/48223/pf0000140987_eng

Clarke, S., Stevens, E., \& Wildy, H. (2006). Rural rides in Queensland: travels with novice teaching principals. International Journal of Leadership in Education: Theory and Practice, 9(1), 75-88. doi:10.1080/13603120500471958

Clarke, S., \& Wildy, H. (2004). Context counts: Viewing small school leadership from the inside out. Journal of Educational Administration, 42(5), 555-572. doi:10.1108/09578230410554061

Creswell, J.W. (2009). Research design: qualitative, quantitative, and mixed-method approaches (3rded). London: Sage.

Cusick, P. A., (2003). A study of Michigan's school principal shortage. Policy Report No. 12. Retrieved from https://www.semanticscholar.org/paper/A-Study-ofMichigan\%27s-School-Principal-Shortage.Cusick/8337015d34cd65cc957a646e294cf0d2dddeeac6 
Davis, H. D., \& Hammond, L. D., (2012). Innovative principal preparation programs: what works and how we know. Planning and changing, 43(1), 25-45. Retrieved from https://files.eric.ed.gov/fulltext/EJ977545.pdf

Doyle, D. \& Locke, G. (2014). Lacking leaders: The challenges of principal recruitment, selection, and placement. Washington D. C: Thomas B. Fordham Institute. Retrieved from https://files.eric.ed.gov/fulltext/ED545231.pdf.

Firman, H., \& Tola, B. (2008). The Future of Schooling in Indonesia. Journal of International Cooperation in Education, 11(1), 71-84. doi: 10.15027/34287

Gene, B., O' Neill, K., Betty, F., David, H., (2003). Good principals are the key to successful schools: six strategies to prepare more good principals. Atlanta: Southern Regional Education Board. Retrieved from https://files.eric.ed.gov/fulltext/ED478010.pdf.

Gronn, P., \& Rawlings-Sanaei, F. (2003). Principal recruitment in a climate of leadership disengagement. Australian Journal of Education, 47(2), 172- 184. https://doi.org/10.1177/000494410304700206

Hallinger, P. \& Heck, R. H. (1998) Exploring the principal's contribution to school effectiveness: 1980-1995. School Effectiveness and School Improvement: An International Journal of Research, Policy and Practice, 9(2),157-191. doi: 10.1080/0924345980090203

Halsey, R. J., Drummond, A., \& Breda, M. v. (2010). A research report on educational leaders and leadership in rural* Australia: profiles, pressures and priorities. Retrieved from www.flinders.edu.au/education/rural.

Hine, G. (2003). Are American schools facing a shortage of qualified adminitrators?. A Journal of Inquiry and Practice, 7(2), 266-277. Retrieved from https://ejournals.bc.edu/index.php/cej/article/view/489/480

Isjuandi, dan Anan, S. (2017). Evaluasi program pendidikan dan pelatihan calon kepala sekolah di Kabupaten Kayong Utara Provinsi Kalimantan Barat : Studi evaluatif model CIPPO pasca pendidikan dan pelatihan. Jurnal Evaluasi Pendidikan, 8(2), 88-101. doi: https://doi.org/10.21009/JEP.082.04

Juliyanti, D., T. (2019). Evaluasi kualitatif program penyiapan calon kepala sekolah di Kota Yogyakarta. (Skripsi). Universitas Negeri Yogyakarta

Kementerian Pendidikan dan Kebudayaan. (2013a). Panduan nasional MBS-SD. Jakarta: Kementerian Pendidikan dan Kebudayaan Direktorat Jenderal Pendidikan Dasar Direktorat Pembinaan Sekolah Dasar.

Kementerian Pendidikan dan Kebudayaan. (2013b). Panduan pelaksanaan manajemen berbasis sekolah di sekolah dasar. Buku IV. Jakarta: Kementerian Pendidikan dan Kebudayaan Direktorat Jenderal Pendidikan Dasar Direktorat Pembinaan Sekolah Dasar.

Kementerian Pendidikan dan Kebudayaan. (2018). Peraturan Menteri Pendidikan dan Kebudayaan RI Nomor 15 Tahun 2018 tentang pemenuhan beban kerja guru, kepala sekolah, dan pengawas sekolah. Jakarta: Kementerian Pendidikan dan Kebudayaan.

Kementerian Pendidikan Nasional. (2007). Peraturan Menteri Pendidikan Nasional Nomor 13 Tahun 2007 tentang Standar Kepala Sekolah/Madrasah. Jakarta: Kementerian Pendidikan Nasional.

Kementerian Pendidikan Nasional. (2010). Peraturan Menteri Pendidikan Nasional Nomor 28 Tahun 2010 tentang penugasan guru sebagai kepala sekolah/madrasah. Jakarta: Kementerian Pendidikan Nasional. 
Kementerian Pendidikan Nasional. (2011a). Buku kerja kepala sekolah. Jakarta: Pusat Pengembangan Tenaga Kependidikan BPSDM PPMP Kementerian Pendidikan Nasional.

Kementerian Pendidikan Nasional. (2011b). Petunjuk pelaksanaan diklat calon kepala sekolah/madrasah. Jakarta: Kementerian Pendidikan Nasional BPSDM dan PMP LPPKS.

Leithwood, K. (2007). Organizational conditions that enhance teaching and learning. In W. D. Hawley (Ed.), The keys to effective schools. Educational reform as continues improvement (pp. 139-152). California: Corwin Press

Leithwood, K., Harris, A., \& Hopkins, D. (2008). Seven strong claims about successful school leaderhip. School Leadership \& Management: Formerly School Organization, 28(1), 22-42. doi:10.1080/13632430701800060

Leithwood, K., \& Levin, B. (2010). Understanding how leadership influences learning. In P. Peterson, E. Baker, \& B. McGaw (Eds.), International Encyclopedia of Education (3rd ed). London: Elsevier, Ltd

Leithwood, K., Louis, K.. S., Anderson, A., \& Wahlstrom, K. (2004). Review of research. How leadership influences student learning. Retrieved from https://www.wallacefoundation.org/knowledge-center/Documents/HowLeadership-Influences-Student-Learning.pdf.

Lingam, G., Lingam, N., \& Raghuwaiya, K. (2014). Challenges for rural school leaders in a developing context: the case of Solomon Islands. International Journal of Social, Behavioral, Educational, Economic, Business and Industrial Engineering, 8(2), 372-380. Retrieved from https://pdfs.semanticscholar.org/2a74/34a523f6e8f3b981fa3e4271e56c6d4bb05 2.pdf

LP2KS. (2016). Lembaga pengembangan dan pemberdayaan kepala sekolah. Retrieved from http://lppks.org/

Marzano, R. J., Waters, T., \& McNulty, B. A. (2005). School leadership that works. The United State of America: ASCD.

Ministry of Education and Culture. (2013). Overview of the education sector in Indonesia 2012. Achievement and challenges. Jakarta: Ministry of Education and Culture.

Mulford, B. (2010). Leadership and management overview. International Encyclopedia of Education ( $\left.3^{\text {rd }} \mathrm{ed}\right)$. Melbourne: Elsevier Science \& Technology.

NAASP \& NAESP. (2013). Leadership matters. What the research says about the importanc of principal leadership. Virginia: NAASP \& NAESP. Retrieved from https://www.naesp.org/sites/default/files/LeadershipMatters.pdf.

Normore, A. H., (2006). Leadership recruitment and selection in school districts: trends and issues. Journal of Educational Thoughts, 40(1), 41-73. Retrieved from https://www.jstor.org/stable/pdf/23767533.pdf?refreqid=excelsior\%3Aa9eda343 16 fa2105b84820b976471531.

Novitasari, R. (2020). Penyiapan calon kepala sekolah dalam kerangka desentralisasi pendidikan di Kabupaten/Kota. (Skripsi). Universitas Negeri Yogyakarta

Republik Indonesia. (2003). Undang-Undang Nomor 20 Tahun 2003 tentang Sistem Pendidikan Nasional. Jakarta: Republik Indonesia.

Republik Indonesia. (2008). Peraturan Pemerintah RI Nomor 74 Tahun 2008 tentang Guru. 
Plessis, P. D. (2014). Problems and complexities in rural schools: challenges of education and social development. Mediterranean Journal of Social Sciences, 5(20), 11091117. doi:10.5901/mjss.2014.v5n20p1109

Priyadi, J. (2017). Pengelolaan latihan kepemimpinan pada diklat ccalon kepala sekolah di Lembaga Pengembangan Pemberdayaan Kepala Sekolah (LPPKS). (Tesis tidak diterbitkan). Solo: Universitas Muhammadiyah Surakarta.

Renihan, P. (1999). In-school leadership for Saskatchewan schools: Issues and strategies. Saskatchewan Educational Leadership Unit, University of Saskatchewan SSTA Research Centre Report No. 99-02. Retrieved from https://saskschoolboards.ca/wp-content/uploads/99-02.htm.

Sayce, D., \& Lavery, S. D. (2013). Beginning the school principalship in rural and remote Catholic schools in Western Australia. Paper presented at the 6th International Conference on Catholic Educational Leadership, The University of Notre Dame Australia. Retrieved from http://researchonline.nd.edu.au/edu_conference/61.

Shoraku, A. (2008). Educational movement toward school-based management in East Asia: Cambodia, Indonesia and Thailand. Paper commissioned for the EFA Global Monitoring Report 2009, Overcoming Inequality: why governance matters. Retrieved from http://hdl.handle.net/123456789/386.

Stake, R.E. (2010) Qualitative research: Studying how things work. London: The Guilford Press.

Styron, R. A., \& Styron, J. L. (2011). Critical issues facing school principals. Journal of College Teaching \& Learning, 8(5), 1-11. doi: 10.19030/tlc.v8i5.8158

Sumintono, B. (2017). Perkembangan penyiapan kepala sekolah di Indonesia. Makalah yang disampaikan pada Seminar Internasional dan Musyawarah Kerja Nasional VI APMAPI. Pontianak, 9 September 2017.

Sumintono, B., Sheyoputry, E. Y. A., Jiang, N., Misbach, I. H., \& Jumintono. (2015). Becoming a principal in Indonesia: possibility, pitfalls and potentials. Asia Pacific Journal of Education, 25(3), 342-352. doi: https://doi.org/10.1080/02188791.2015.1056595

Sun, J., \& Leithwood, K. (2015) Direction-setting school leadership practices: a metaanalytical review of evidence about their influence. School Effectiveness and School Improvement 26(4), 499-523. doi: https://doi.org/10.1080/09243453.2015.1005106

Suyud, Andriani, D. E., Purwanto, N. A., (2018). Laporan penelitian. Evaluasi kualitatif program penyiapan kepala sekolah di Daerah Istimewa Yogyakarta. Yogyakarta: Universitas Negeri Yogyakarta

Tuck, A. (2009). Small school challenges, learning lessons from small school headteachers. Retrieved from: www.ncsl.org.uk/researchassociates.

Whitaker, K., S. (2003). Principal role changes and influence on principal recruitment and selection, Journal of Educational Administration, 41(1), 37 - 54. doi: http://dx.doi.org/10.1108/09578230310457420

Wilson, E., \& Brundrett, M. (2005). Leading the small rural primary school: the challenges of headship. Education -3-13 BPRS, 33(3), 44-48. doi:10.1080/03004270585200331

Wise, D., (2015). Emerging challenges facing school principals. NCPEA Educational Leadership Review, 16(2), 103-115. Retrieved from https://files.eric.ed.gov/fulltext/EJ1105451.pdf 
World Bank. (2012). Implementation of school-based management in Indonesia. Retrieved from http://documents.worldbank.org/curated/en/537441468042883853/pdf/NonAscii FileName0.pdf

Zeitoun, P., \& Newton, R.M. (2002). Evaluative report. Strategies for reinventing the principalship. Retrieved from https://files.eric.ed.gov/fulltext/ED469274.pdf 